\title{
PPARs and Metabolic Disorders Associated with Challenged Adipose Tissue Plasticity
}

\author{
Patricia Corrales $^{1, *}$, Antonio Vidal-Puig ${ }^{2,3}$ and Gema Medina-Gómez ${ }^{1, *(D)}$ \\ 1 Área de Bioquímica y Biología Molecular, Departamento de Ciencias Básicas de la Salud, \\ Facultad de Ciencias de la Salud, Universidad Rey Juan Carlos, Avda. de Atenas s/n. Alcorcón, \\ 28922 Madrid, Spain \\ 2 Metabolic Research Laboratories, Wellcome Trust MRC Institute of Metabolic Science, \\ Addenbrooke's Hospital, University of Cambridge, Cambridge CB2 0QQ, UK; \\ ajv22@medschl.cam.ac.uk \\ 3 Wellcome Trust Sanger Institute, Hinxton, Cambridgeshire CB10 1SA, UK \\ * Correspondence: patricia.corrales@urjc.es (P.C.); gema.medina@urjc.es (G.M.-G.); \\ Tel.: +34-91-4888632 (G.M.-G.)
}

Received: 19 June 2018; Accepted: 18 July 2018; Published: 21 July 2018

\begin{abstract}
Peroxisome proliferator-activated receptors (PPARs) are members of a family of nuclear hormone receptors that exert their transcriptional control on genes harboring PPAR-responsive regulatory elements (PPRE) in partnership with retinoid X receptors (RXR). The activation of PPARs coordinated by specific coactivators/repressors regulate networks of genes controlling diverse homeostatic processes involving inflammation, adipogenesis, lipid metabolism, glucose homeostasis, and insulin resistance. Defects in PPARs have been linked to lipodystrophy, obesity, and insulin resistance as a result of the impairment of adipose tissue expandability and functionality. PPARs can act as lipid sensors, and when optimally activated, can rewire many of the metabolic pathways typically disrupted in obesity leading to an improvement of metabolic homeostasis. PPARs also contribute to the homeostasis of adipose tissue under challenging physiological circumstances, such as pregnancy and aging. Given their potential pathogenic role and their therapeutic potential, the benefits of PPARs activation should not only be considered relevant in the context of energy balance-associated pathologies and insulin resistance but also as potential relevant targets in the context of diabetic pregnancy and changes in body composition and metabolic stress associated with aging. Here, we review the rationale for the optimization of PPAR activation under these conditions.
\end{abstract}

Keywords: PPAR; metabolism; adipose tissue; obesity; pregnancy; aging; caloric restriction

\section{Introduction}

Approximately $39 \%$ of the world's adult population is overweight and no less than $13 \%$ is obese. Obesity is currently the most prevalent chronic metabolic disorder and its current prevalence is predicted to triple by 2030 according to the World Health Organization (WHO). Beyond the obvious physical constraints and associated psychological stress, the main cause of morbimortality associated with obesity is its associated cardiometabolic metabolic pathologies, namely insulin resistance, dyslipidemia, and type 2 diabetes (T2D), a cluster of pathological entities globally designated as metabolic syndrome (MetS). Under normal circumstances, an excess of calories is considered advantageous for the organism as long as it is efficiently stored in the adipose tissue in the form of fat. However, excessive amounts of fat, beyond the available storing capacity of the adipose tissue (AT), or when accreted at a relatively fast pace, may overwhelm the functional capacity of the organ. When that happens, the excess of nutrients can, to a certain extent, be burnt, and/or alternatively 
be accumulated ectopically in other metabolically relevant organs, such as the liver, skeletal muscle, kidney, and pancreas-organs not purposely designed to be a main storage compartment. In these organs, as in the white AT (WAT), the excessive nutrient load induces metabolic stress causing lipid-related toxicity, a known cause for insulin resistance and inflammation [1,2].

Given these gloomy prospects, it has become increasingly necessary to identify pathogenic molecular mechanisms and diagnostic and prognostic biomarkers that can predict evolution and potential outcomes, as well as suitable therapeutic targets. Although metabolic syndrome has by definition different potential pathogenic entrances, we believe that given the relevance of its association with obesity, it is quite likely that in a high percentage of these predominantly obese patients, the dysfunction of their adipose tissue becomes a main contributor to subsequent associated complications. Peroxisome proliferator-activated receptors (PPARs) play important regulatory roles that control the homeostasis of the adipose tissue through the regulation of the balance between anabolic and oxidative processes. In this regard, we think that the PPARs associated with specific processes could be targeted, given their objective to beneficially improve insulin sensitivity, and that their agonists could be suitable candidates in the therapeutic arsenal to treat MetS.

PPARs are a group of ligand-activated nuclear hormone receptors. These transcription factors exist within a protein superfamily, which includes the receptors for retinoids, vitamin D, steroids, and thyroid hormones. These nuclear receptors bind to PPAR-responsive regulatory elements (PPRE) and heterodimerize with the retinoid $X$ receptors (RXR), translocating to the nucleus where they contribute to transactivate and/or transrepress specific genes. In some respect, the PPARs are well placed to connect the environment represented by nutritional inputs [3,4] to specific genetic programs controlling genes involved in inflammation, adipogenesis, lipid metabolism, and glucose homeostasis [5].

There are three different isoforms of PPARs in mammals: PPAR $\alpha, \operatorname{PPAR} \beta / \delta$, and PPAR $\gamma$. The three PPARs isoforms show structural similarities. However, despite their similarities, the isoforms exhibit differences in tissue distribution, ligand specificities, and functions. Recently, PPARs have been suggested to relate to the crossroads of obesity, diabetes, inflammation, and cancer [6]. Their topographic distribution and context-dependent regulation may be more important than the specific repertoire of genes they regulate, and collectively, they play an essential role in the maintenance of metabolic homeostasis [7-9].

PPAR $\alpha$ is predominantly expressed in the liver and to a lesser extent in muscle, heart, bone, and brown adipose tissue (BAT), all of which are eminently prooxidative tissues rich in mitochondria content. In the liver, PPAR $\alpha$ is activated under energy deprivation conditions. It is part of the adaptive response to fasting, and its main net contribution is to increase ATP production from $\beta$-oxidative phosphorylation, a process that requires coupling to the ancillary systems related to fatty acid transport and ketogenesis $[10,11]$. Moreover, the role of PPAR $\alpha$ in controlling the expression of genes involved in lipid metabolism goes beyond its immediate effect of increasing energy availability in the liver, by also providing energy for supply to the peripheral tissues according to energetic demands in the heart, muscle, kidney, and brown AT during fasting. Through its prooxidative anti lipotoxic effects, PPAR $\alpha$ ligands are successfully used therapeutically to treat primary and secondary forms of hypertriglyceridemia particularly associated with MetS [12,13].

PPAR $\beta / \delta$ is ubiquitously expressed but is particularly active in skeletal muscle, where it contributes to sustain the energy requirements for physical exercise by upregulating fatty acid $\beta$-oxidation specifically during fasting [14]. This PPAR isoform is also expressed in adipocytes and macrophages, where it reduces the expression of proinflammatory markers, such as nuclear factor kappa B (NF-kB), conferring the systemic anti-inflammatory activity of this isoform $[15,16]$.

$\operatorname{PPAR} \gamma$ is predominantly expressed in adipose tissues, both white and brown, where it plays an important anabolic role in facilitating fat storage, adipogenesis, and thermogenesis $[17,18]$. There are two main isoforms, PPAR $\gamma 1$ and PPAR $\gamma 2$, differentiated by an extra exon of 90 nucleotides in the end terminus of the $\gamma 2$ isoform. PPAR $\gamma 1$ has a widespread distribution and seems to support a sort of housekeeping metabolic role, which is particularly relevant in the intestine, macrophages, the 
liver, muscle, pancreatic $\beta$-cells, bone, placenta, and adipose tissue. Conversely, the expression of the PPAR $\gamma 2$ isoform is restricted under physiological conditions to adipose tissues. However, under conditions such as long-term overnutrition or obesity, PPAR $\gamma 2$ is induced de novo in the liver and skeletal muscle, in parallel with the development of ectopic accumulation of lipids in these and other organs [19]. Both PPAR $\gamma$ isoforms contribute to the uptake of glucose and lipids, and when expressed ectopically, they promote safe deposition of lipids in peripheral tissues, such as the liver, muscle, and adipose tissue. When interpreting the role of PPAR $\gamma$ isoforms on the maintenance of energy homeostasis, it is important to consider the effect that the ectopic induction of PPAR 2 contributes to facilitating the reorganization of the inter-organ communication of nutrients and energy fluxes, which will help to understand how, when defective, it may lead to insulin resistance [20]. PPAR $\gamma$ has been heavily studied in part because the availability of its pharmacological agonists (TZDs) ligands, such as rosiglitazone and pioglitazone, both known to improve insulin resistance and exert anti-inflammatory effects in the adipose tissue [21-23] and on a systemic level. Such effects are potentially important in the treatment of obesity and T2D but also could have therapeutic value in physiological states, such as pregnancy and aging, characterized by insulin resistance and changes in body composition.

In this review, we summarize the contribution of PPARs to the maintenance of the adipose tissue physiology and discuss the pathogenic role mediated by dysfunctional PPARs in different contexts, characterized by defective adipose tissue expandability or functional failure associated with the development of insulin resistance and T2D, such as obesity, pregnancy, and aging.

\section{Adipose Tissue Physiology and Lipotoxicity}

Two main types of adipose tissue-white and brown adipose tissue (WAT and BAT, respectively) - exist. WAT is an endocrine organ that stores and mobilizes energy reserves as fat, whereas BAT uses lipids to produce heat by promoting uncoupled fatty acid oxidation converting nutrients in heat upon $\beta$-adrenergic stimulation or cold exposure. Both white and brown are necessary and contribute to maintain whole-body energy homeostasis [24].

Beyond its storage function, the WAT is an important endocrine organ responsible for synthesizing hormones, chemokines, and cytokines that modulate food intake, insulin sensitivity, or inflammation, which contribute to the maintenance of whole metabolism functionality $[25,26]$. In healthy conditions, the main function of the subcutaneous WAT is lipid storage of free fatty acids (FFAs) as triglycerides (TGs) in large unilocular droplets. However, in the context of chronic energy surplus leading to weight gain, the subcutaneous WAT adapts by increasing the cell size of the existing adipocytes (hypertrophy) and/or increasing the number through differentiation of new adipocytes (hyperplasia). Initially, this adaptation is sufficient to store lipids in the WAT, preventing them from ectopically accumulating in the liver or muscle. But, once adipose tissue storage capacity is exceeded above an individualized threshold, where the subcutaneous WAT cannot accommodate the excess of lipids, then these lipids are ectopically deposited in the liver, pancreas, muscle, kidney, and other important peripheral tissues. As obesity progresses the adipose tissue becomes inflamed and fibrotic, further contributing to the dysfunction of the AT. Both the failure to take upon lipids and to appropriately mobilize them decreases the metabolic flexibility of the WAT and exerts a knock-on effect on other organs leading to the development of metabolic abnormalities, such as dyslipidemia and peripheral insulin resistance [24,27].

In contrast to the unique, large lipid droplets of white adipocytes, BAT stores TGs in multilocular lipid droplets. This distribution of lipids in small vesicles helps to titrate the release of lipids destined to be oxidized by the mitochondria to produce heat through "uncoupling" of oxidative phosphorylation of FFAs stimulated by $\beta$-adrenergic sympathetic nervous system (SNS) typically observed in cold exposure. By oxidizing nutrients, BAT activation counteracts obesity, reduces TGs in the plasma, and reduces atherosclerosis development [28,29]. Furthermore, another type of thermogenic adipocytes can also be found interspersed in white fat depots, such as cells known as 'brite/beige' adipocytes [30]. This type of adipocytes appears to respond to thermogenic stimulation and, in principle, are expected 
to contribute to the regulation of body weight and the improvement of insulin resistance [31]; however, their functional relevance has not been clearly demonstrated so far.

Although there is a correlation between fat mass and insulin resistance, the adipose tissue mass by itself is not the main determinant factor linking obesity and insulin resistance. The relative mismatch between storage capacity and lipid load supply could be considered to be more relevant. By upregulating the capacity of adipose tissue to expand and store and/or by decreasing the supply of lipids, we may tweak this balance, preventing the mismatch. PPARs are key transcriptional regulators of this balance by contributing to increase the storage capacity of the adipose tissue and also, through their prooxidative effects, to decrease the demand for storage or the supply of lipids. A second layer of complexity comes from the knock-on positive effect, that by restoring the balance of the AT, it will exert an influence on the function of other metabolic tissues as a result of removing the toxic effects determined by ectopic fat deposition.

\section{PPARs and Fat Mass Expansion and Function}

The binding of ligands to PPAR $\gamma$ results in molecular changes, including the dissociation of co-repressors and the recruitment of co-activators, ultimately leading to changes in the coordinated expression of networks of genes functionally linked to adipogenesis, lipid metabolism, inflammation, thermogenesis, and body glucose homeostasis. PPAR $\gamma$ activation facilitates fat accretion and retains the functionality of adipose tissue by coordinating adipogenesis, fat transport, and lipolysis upon reaching an individualized threshold of adipose tissue mass. Defects in PPAR $\gamma$, either in the form of mutants or secondary-to-decreased expression, compromises adipose tissue function, plasticity, and lipotoxicity. This is accompanied by the development of peripheral insulin resistance and ultimately global metabolic disruption. Restoration/maintenance of PPAR $\gamma$ functionality senses the lipid load and enables the recovery of the homeostasis of essential metabolic pathways (Figure 1).

PPAR $\alpha$ is preferentially expressed in liver, where its activation is essential to generate energy, particularly under conditions of energy deprivation paradigms by promoting fatty acid uptake and oxidation [10]. This isoform exerts a pleiotropic effect controlling liver glucose metabolism, as observed in mice where PPAR $\alpha$ activation by fibrates decreases expression levels of glucokinase [32] and suppresses pyruvate transformation to acetyl-CoA [33]. PPAR $\alpha$ is also expressed in the WAT, where its activation elicits systemic effects in rodents by decreasing adiposity and ameliorating the insulin resistance in obese mouse models [34]. Moreover, it has been reported that treatment with PPAR- $\alpha$ agonists also increases the expression of adiponectin by the WAT $[34,35]$ and decreases the tumor necrosis factor $\alpha$ (TNF- $\alpha$ ) levels $[36,37]$. This anti-inflammatory effect in the WAT suggests PPAR $\alpha$ activation has the capacity to improve insulin resistance and ameliorate obesity. In the BAT, PPAR $\alpha$ exerts a thermogenic effect, cooperating with the peroxisome proliferator-activated receptor gamma coactivator 1-alpha (PGC1 $\alpha$ ) to control lipid oxidation and thermogenesis in response to $\beta$-adrenergic stimulation in response to cold exposure [38]. Moreover, activation of PPAR $\alpha$ in obese mice increases energy expenditure and activates thermogenic pathways that facilitate weight loss [39]. Because of PPAR $\alpha$ agonists' prooxidative actions, activators of this nuclear hormone receptor may be used to improve obesity-induced insulin resistance.

PPAR- $\beta / \delta$ in the BAT regulates the fatty acid oxidation $[14,40]$ and the thermogenic response contributing to the induction of the uncoupling protein 1 (Ucp1) expression and leading to the reduction of the WAT mass [40]. Moreover, this isoform may also have an anti-inflammatory effect when activated [41,42]. The metabolic function of PPAR- $\beta / \delta$ in the WAT has been much less studied, although it is known that this isoform facilitates preadipocyte differentiation [43]. Nowadays, PPAR- $\beta / \delta$ activators are under study for their clinical advantages in treating obesity. 


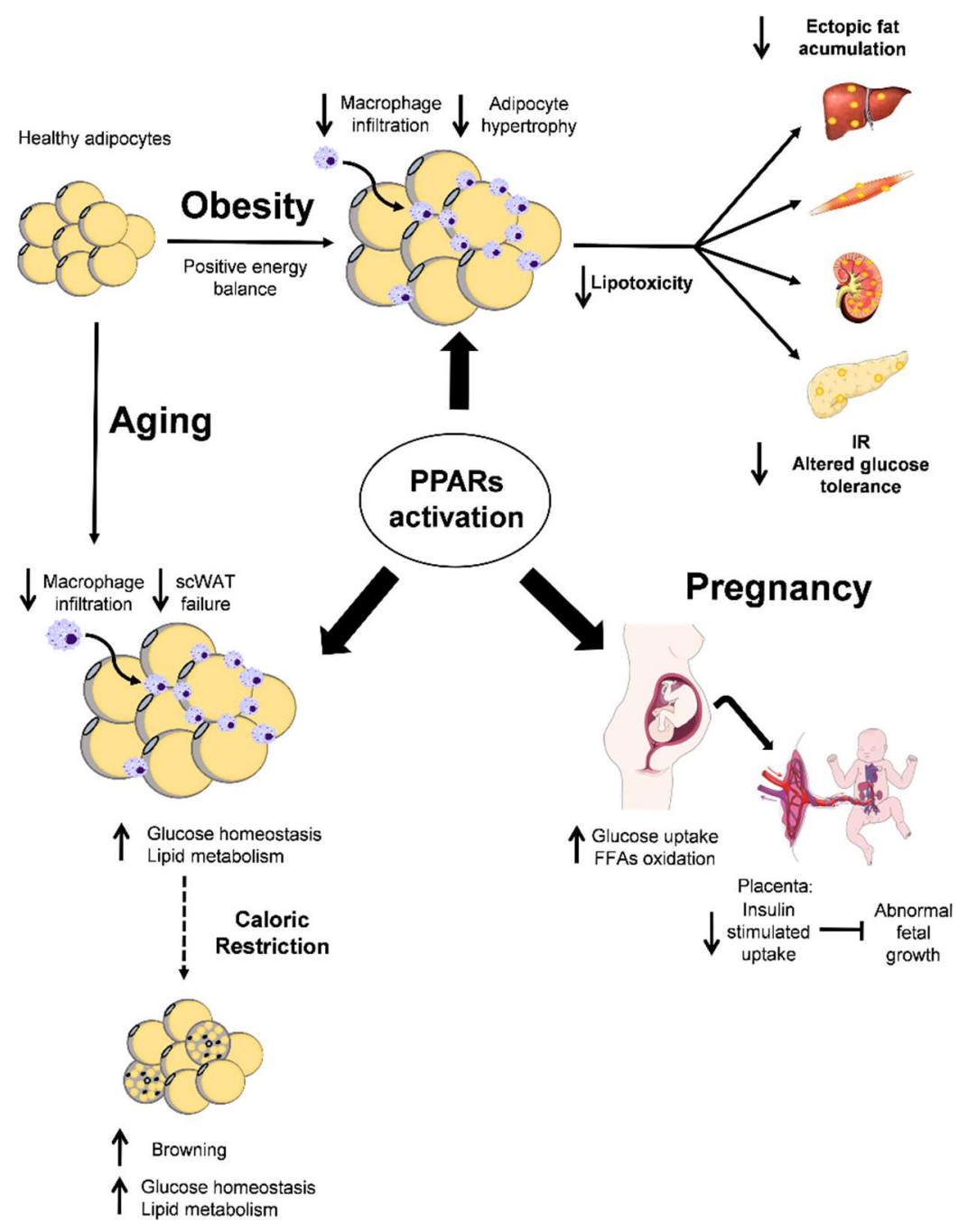

Figure 1. Overview of the effects of peroxisome proliferator-activated receptors (PPARs) activation in obesity, pregnancy, and aging. In obesity, PPARs activation decreases fibro-inflammation and ectopic fat accumulation in the adipose tissue (AT). In pregnancy, PPARs activation stimulates glucose uptake and fatty acid oxidation in the mother, while the placenta decreases insulin uptake to ameliorate abnormal fetal growth. In aging, this PPARs activation increases the glucose uptake and lipid metabolism in the subcutaneous white AT (scWAT). Moreover, both PPARs activation and caloric restriction (CR, dotted arrow) in aging promote browning in the AT, which improves the whole-body metabolism. The final effect of PPARs activation in all situations is the improvement of insulin resistance (IR). $\rightarrow$ PPARs activation; $\longrightarrow$. effects or PPARs activation; $-\rightarrow \mathrm{CR}$ effect; $\longrightarrow$ inhibition; $\uparrow$ increase or $\downarrow$ decrease effect.

PPAR $\gamma$ is expressed predominantly in the adipose tissues, where it acts as sensor of lipids, hormones, vitamins, and endogenous metabolites. This isoform is an important regulator of adipocyte differentiation, fat storage as triglyceride, and energy homeostasis. Both isoforms of PPAR $\gamma$, PPAR $\gamma 1$ and PPAR $\gamma 2$, are necessary for the adipogenic function, and alteration in their expression increases susceptibility to lipodystrophy, insulin resistance, and T2D [44]. PPAR $\gamma$ is necessary for fat cell differentiation in all adipose depots and contributes to define the maximum threshold of expansion of the WAT. This is supported by studies showing that ectopic presence of PPAR $\gamma$ in non-adipogenic cells trans-differentiates them into mature adipocytes [45,46]. Moreover, PPAR $\gamma$-deficient mice cannot develop adipose tissue [47,48]. Mice with PPAR $\gamma$ knockout in mature cells also develop insulin resistance and hyperlipidemia through dysregulation of molecular pathways of insulin signaling, 
FFAs uptake, and lipolysis [49]. Specific knockdown of the PPAR $\gamma 2$ isoform in mice results in adipose tissue dysfunction and insulin resistance [2]. Moreover, when the adipose tissue of this model is challenged with increased lipid supply, as characteristically observed in a leptin-deficient obese $(o b / o b)$ background (POKO mouse [50]), these mice are precociously more insulin resistant, as young as 4 weeks, an age where the differences in fat mass in comparison with an $o b / o b$ mice are not well established. In addition, the POKO mice became diabetic and hyperlipidaemic at 16 weeks of age, despite weighing less and having less fat than an $o b / o b$ mouse at that age, with increased toxic reactive lipid species in different tissues, behaving like a mouse model of lipotoxicity and metabolic syndrome [51]. This reinforces the concept that it is not the absolute amount of fat mass, but the mismatch between nutrient supply and storage capacity that results in dysfunctional adipose tissue and metabolic stress. Furthermore, in states of obesity, the expression of PPAR $\gamma$ decreases with the consequent induction of a high grade of inflammation, angiogenesis, and fibrosis in the WAT [52] and low levels of adiponectin, which limits the adipose tissue expansion. Consistent with this, patients with mutations of PPAR $\gamma$ develop lipodystrophy and insulin resistance [53]. Conversely, increased expression of PPAR $\gamma$ protects from the insulin resistance associated with obesity [54].

TZDs, the pharmacological agonists of PPAR $\gamma$, have been used clinically as antidiabetic agents, and their beneficial effects are well documented in relation with insulin resistance and obesity. The activation of PPAR $\gamma$ by TZDs in the WAT improves WAT expansion, alleviates peripheral lipotoxicity and normalizes adipokine secretion [24]. This activation improves the WAT's ability to store lipids and reduces lipotoxicity in the liver and muscle by the activation of metabolic pathways implicated in FFA oxidation. The metabolic effects include lower levels of TGs in circulation, in the liver, and muscle, coupled with increased TGs in the adipose tissue [52]. The expression of TNF- $\alpha$ is also inhibited using TZDs [55]. Furthermore, PPAR $\gamma$ stimulates adiponectin production in the WAT, which contributes to further stimulating FFA oxidation, reducing hepatic glucose, and increasing the use of glucose by muscle [56]. Recently, it has been shown that PPAR $\gamma$ activated by TZDs promotes the expression of the fibroblast growth factor family (FGF1 and FGF21) showing the key role of the PPAR $\gamma$-FGF axis, which contributes to the remodeling of the adipose tissue and the maintenance of metabolic homeostasis $[57,58]$. Thus, the result of pharmacological intervention in obesity with TZDs is the improvement of insulin sensitivity derived from the effects of TZDs improving adipose tissue function despite the associated increase in fat mass.

TZDs can promote browning in the WAT. Activating PPAR $\gamma$ [59] increases the expression of BAT-specific genes, such as Ucp-1 and Prdm16 [60], via Sirt1 [61], priming the oxidative capacity of the adipose tissue through its transformation into brown-like adipocytes. These effects confer thermogenic properties by promoting mitochondrial biogenesis in the WAT, which can help in the remodeling of the adipose tissue and insulin resistance improvement under obesity conditions.

Therefore, the role of PPAR $\gamma$ improving glucose metabolism and insulin sensitivity is well established and provides insights into the molecular regulation of adipose tissue expansion in normal and obese/lipodystrophy pathological states but also in other situations in which the adipose tissue is physiologically stressed, such as pregnancy and aging.

\section{PPARs and Pregnancy}

Pregnancy involves hormonal and metabolic adaptations that directly affect maternal adiposity. In the early stages of pregnancy, the adipose tissue mass expands due to an increase in the lipid accumulation (known as a primarily anabolic phase). There is an increase in lipid synthesis and fat storage that prepare the mother's metabolism for the prospective increase in fetal energy needs at a later phase. This increase in lipid/energy supply is enabled by maternal hyperphagia and improved insulin sensitivity, which stimulates FFAs synthesis in adipocytes and the uptake of FFAs from circulating TGs for preferential accumulation in the adipose tissue. Moreover, the production of hormones, such as progesterone, cortisol, and leptin, also contribute to facilitated fat storage and adipocyte hypertrophy. However, in contrast to this early anabolic phase of gestation, the adipose mass decreases in a later 
phase (known as a net catabolic phase). During the late phase of gestation, IR and a low grade of inflammation, especially in the adipose tissue, are developed, which should be considered as a physiological adaptation. Moreover, the decrease in insulin sensitivity enhances lipolysis, helping to mobilize the stored TGs. The human placental lactogen (Hpl) also stimulates lipolysis in adipocytes, coupled with the decrease in FFAs uptake from TGs in the plasma. The net result of these changes is a reduction in the adipose tissue mass and an increased glucose flux from mother to fetus. Although the physiological IR developed in the late phase of pregnancy is well documented, the mechanisms causing the changes in the adipose tissue and insulin resistance during pregnancy are still unclear.

Together with the exacerbated insulin resistance, insulin secretion may also become inadequate to meet the increased demands in the late stage of pregnancy, leading to gestational diabetes mellitus (GDM). Moreover, their offspring have an increased risk of perinatal complications, obesity, and diabetes in adulthood [62]. GDM is defined as glucose intolerance on first recognition during pregnancy [63] and characteristically shows altered plasma adipokine levels, inflammation, deregulation of the insulin signaling pathway, and oxidative stress [64-66]. The mechanisms underlying the GDM are not fully understood; however, it is known the association between inappropriate PPAR $\gamma$ function/levels and GDM through its function in both the adipose tissue and the placenta $[67,68]$.

During early pregnancy, as in obesity, the mechanisms leading to energy storage and adipose tissue expansion are activated. It has also been reported that in advanced pregnancy, PPAR $\gamma$ declines, thus accelerating adipose tissue insulin resistance and facilitating lipolysis in the subcutaneous adipose tissue of obese pregnant women with GDM [67]. Moreover, PPAR $\alpha$ and PPAR $\beta / \delta$ expression also decreases in adipose tissue from obese pregnant women and/or women with GDM [69]. In pregnant mouse models, the association between a decrease in PPAR $\gamma$ expression, exacerbated lipolysis in the AT [70], and the subcutaneous AT dysfunction has been reported. In agreement with this, we have shown that genetic ablation of PPAR $\gamma 2$ in pregnant mice is associated with poor AT expandability and the worsening of insulin resistance [71]. The contribution of PPAR $\gamma 2$ is also important for the process of pancreatic $\beta$-cell mass expansion and adaptation in murine models of MetS [50,71,72]. A missing study is the PPAR $\gamma$ deleted specifically in the pancreatic $\beta$-cell in order to study the mechanisms implicated in its adaptation when pregnancy occurs. Furthermore, it has been reported that the use of PPAR $\gamma$ agonists reverse the insulin resistance associated with late pregnancy in murine models [65]. For this reason, more studies are necessary to elucidate the potential of PPAR $\gamma$ agonism to overcome defects in pregnancy related to insulin resistance and GDM.

The role of PPARs in the placenta is potentially important. The placenta is an endocrine gland that synthesizes the peptides and steroid hormones during pregnancy that are essential for the maintenance of mother and fetus. Regarding their roles, PPAR $\alpha$ null female mice become diabetic during pregnancy and have an increased risk of spontaneous abortion [73]. PPAR $\delta$ also has a relevant role in embryonic, decidual, and placental function [74]. Moreover, PPAR $\delta$ and PPAR $\gamma$ null mice are not viable and exhibit a failure in the development of the placenta [75]. PPAR $\gamma$ is downregulated in the placenta in human patients with GDM. PPAR $\gamma$ has anti-inflammatory effects in the placenta and modulates embryogenesis, implantation, trophoblast invasion, and maternal spiral artery transformation [76]. Moreover, it has been demonstrated that reduced expression of PPAR $\gamma$ in placental tissues and serum is contributing to the development of preeclampsia, a specific pregnancy disorder in humans that contributes to maternal mortality [77]. However, in a mice study, PPAR $\gamma$ expression was upregulated in the placentas of diabetic pregnant mice [78]. These contradictory effects may lead to specie-specific effects and would need to be further elucidated to be used to improve the GDM in pregnancy.

\section{PPARs and Aging}

Aging is a complex and multifactorial progressive physiological decay process, associated with an increased risk of metabolic disorders, such as obesity, insulin resistance, and other manifestations related to MetS, which are exacerbated by age. Moreover, aging is associated with changes in body 
composition characterized by increased total adiposity and topographical redistribution of adipose tissue defined by preferential loss of the subcutaneous WAT coupled with expansion of adipose in the visceral compartment $[79,80]$. Accretion of visceral, rather than subcutaneous WAT has been associated with the development of insulin resistance. The expansion of the intraabdominal adipose tissue may also be considered another example of peripheral lipotoxicity determined by a primary defect in the subcutaneous WAT. An important concept is the fact that as we age, the adipose tissue ages as other tissues, such as muscle or the liver, do. When muscle becomes frail/sarcopenic, with decreased oxidative capacity, lipids are redirected to the adipose tissue for storage precisely at a time when the adipose tissue itself has aged and is less functional and competent to deal with increasing metabolic challenges. In this regard the adipose tissue of the aged individual is subjected to even more lipid load, increasing the chances of AT dysfunction and peripheral lipotoxicity. In fact, ectopic fat accumulation in muscle is observed in lean elder individuals.

This conflict between increased storage demand and age-related decay results in increased adiposity coupled with macrophage infiltration and inflammation that interferes with insulin signaling. Thus, a key factor determining the shift of the AT towards the inflammatory state is the mismatch between the demand for storage and capacity [81]. Moreover, as inflammatory cells can be high-level producers of selective fibrotic molecules [82], the old adipose tissue characteristically shows age-related fibro-inflammatory changes. Fibrosis is a disease process that deposits collagen-rich extracellular matrix (ECM) in an attempt to remodel and repair the tissue morphology and organ functionality of a failing organ. Transforming growth factor $\beta$ (TGF- $\beta$ ) plays a key role in fibrosis, modulating the balance between the rate of synthesis and the degradation of matrix collagen proteins. It has been reported that a role for PPAR $\gamma$ is as a potent antifibrotic factor in the kidney [83]. In the AT, it has also been reported that TGF- $\beta$, apart from increasing collagen deposition, also increases mechanical stress on the adipocyte membrane and the rigidity of AT, compromising its further expansion. This rigid matrix can result in cell death by necrosis. In this situation, PPAR $\gamma$ agonists decrease collagen levels in the AT and confers a more flexible environment for the adipocyte growth and remodeling [84]. Thus, we could speculate that age-related defects in the adipose tissue remodeling may also contribute, particularly in the context of obesity, to exacerbated pathological conditions linked to insulin resistance [85].

Based on this evidence it is conceivable that age-related changes in PPARs may contribute to some of these pathological changes. However, at present, there is a paucity of information about how PPARs activation may contribute to delay or ameliorate these pathological changes.

Given the importance of PPAR $\gamma$ in adipose tissue biology, it is important to determine the contribution of PPAR $\gamma$ dysfunction in aging-associated metabolic decline. It is well documented, the role of PPAR $\gamma$ in coordinating gene expression programs of adipocyte differentiation, lipid storage, and lipolysis. Previous reports also suggest that PPAR $\gamma$ deficiency selectively in the subcutaneous AT during aging is associated with increased AT expansion that is associated with the development of insulin resistance [86]. Moreover, other studies have shown that oxidative stress and reactive oxygen species (ROS) production (characteristically observed in aging and linked to insulin resistance in adipocytes) modulate other proinflammatory pathways, linking PPAR $\gamma$ dysfunction with inflammation [87], such as NF- $\mathrm{kB}$ [88], likely to contribute to altered tissue expansion and inflammation and associated age-related insulin resistance. In addition, mitochondria, as the core organelle required to maintain cellular functionality and glucose and lipid homeostasis [89], have been suggested as key contributors to adipocyte formation through ROS signaling [90]. In aging, as in obesity, mitochondrial enzyme expression is reduced in the AT leading to decreased oxygen consumption and oxidative phosphorylation [91,92] in response to lipid overload, usually coupled with decreased AT insulin sensitivity [93]. Interventions with TZDs induce mitochondrial biogenesis, ROS, and remodeling in the AT, enhancing fatty acid oxidation and oxygen consumption, which seems to contribute to changes in the whole-body energy metabolism and insulin sensitivity [94]. Moreover, insulin resistance in elderly patient populations has been associated with decreases in mitochondrial oxidative phosphorylation [95]; however, further work is required to identify the 
mediators of nuclear-encoded mitochondrial genes induced by PPAR $\gamma$ ligand-dependent mechanisms that could be helpful during aging.

Furthermore, both PPAR $\alpha$ and PPAR $\gamma$ decrease in the kidney with aging. This is correlated with accelerated oxidative stress and counteracted by the antioxidative action of caloric restriction [96]. All these studies suggest that defective PPARs are important for the defects in energy expenditure and lipogenic function leading to lipid accumulation in the whole body during aging. From this, it is conceivable that targeting these isoforms could be a helpful approach to reduce or prevent age-associated metabolic decline and protect from lipid accumulation and lipotoxicity. It could be speculated that TZDs treatment may help to reduce the side effects of weight gain in the elderly by minimal/function specific PPAR $\gamma$ activation stimulating insulin sensitivity without promoting adipogenesis [97]. But, in any case, it would be important to overcome some of the negative effects observed when using TZDs in the elderly. Amongst them is the increased bone marrow adiposity and reduced bone formation, resulting in osteopenia, bone fracture, and other complications [98]. Moreover, the use of some PPAR agonists had to be withdrawn from the United States (US) and European markets because of associated complications, such as edema, weight gain, macular oedema, heart failure, and bladder cancer, that have been associated side effects [99]. These are important drawbacks but potentially addressable with increased knowledge of the specific PPAR $\alpha$ dependent pathways mediating them.

An added value of the PPAR $\alpha$ agonists occurs in the muscle. Old age is associated with dyslipidemia, which together with the increase and dysfunction of the AT can lead to preferential deposition of TGs in skeletal muscle, ultimately leading to IR. Agonists of PPAR $\alpha$ and PPAR $\beta / \delta$ have been used to treat dyslipidemia by increasing oxidative capacity in muscle fibers and improving insulin sensitivity [100]. Furthermore, TZDs as specific activators of PPAR $\gamma$ are used as insulin sensitizers and as regulators of FFAs storage, which may prevent intramuscular lipid accumulation [80] and maintain skeletal muscle insulin action [101].

Caloric restriction (CR) is another therapeutic paradigm representing a non-pharmacological intervention to efficiently delay the deleterious effects of age-related metabolic diseases [102]. Previous studies in animal models have shown that CR exerts physiological effects leading to reduced body weight and glucose and insulin serum levels [103]. Moreover, the reduction of adiposity by CR [104] or fat removal [105] have been demonstrated to ameliorate age-associated insulin resistance. Of note, CR alters the expression of genes that are regulated by PPARs and that are involved in lipid metabolism and insulin signaling. In some ways, the beneficial effects derived from fasting may be mediated, at least in part, by these nuclear receptors [106]. The effects of CR in the AT on PPAR $\alpha$ and PPAR- $\beta / \delta$ have not been shown yet, but it is known that CR and PPAR $\gamma$ agonists can improve the reduced mitochondrial function in the WAT due to aging and obesity [107]. Moreover, it has been reported that CR induces BAT functionality [102], and it has been speculated that the induction of a brown fat phenotype in the WAT by CR or PPAR $\gamma$ agonists would result in an increased mitochondrial functionality with beneficial effects on aging and metabolism. Due to the improvement in aging conditions by using PPARs agonists, more studies are needed to document the role of PPARs on adipose tissue plasticity during aging.

\section{Conclusions}

Defective adipose tissue synergizes with the age-related metabolic defects to exacerbate metabolic diseases. Thus, the understanding of cellular mechanisms governing the plasticity of adipose tissue should help to understand and provide therapeutic rationale to address metabolic disorders. Understanding the molecular alterations that determine the impaired adipose tissue plasticity may identify therapeutic targets to optimize AT expandability and function. Thus, PPARs should be considered candidates to improve age-related metabolism through their influence in the balance between anabolic and catabolic processes and by limiting unwanted inflammatory reactions that may compromise lipid and glucose homeostasis. Thus, PPARs may have the clue to restore, delay, and 
improve the metabolic balance in those conditions that render someone particularly susceptible to developing insulin resistance, such as obesity, pregnancy and aging.

Author Contributions: P.C., A.V.-P., and G.M.-G. wrote the paper.

Acknowledgments: Research conducted for this publication was supported by Ministerio de Economía y Competitividad (BFU2013-47384-R and BFU2016-78951-R) and Comunidad de Madrid (S2010/BMD-2423 and B2017/BMD-3684).

Conflicts of Interest: The authors declare no conflict of interest.

\section{Abbreviations}

$\begin{array}{ll}\text { T2D } & \text { Type } 2 \text { diabetes } \\ \text { MetS } & \text { Metabolic Syndrome } \\ \text { AT } & \text { Adipose tissue } \\ \text { PPARs } & \text { Peroxisome proliferator-activated receptors } \\ \text { PPRE } & \text { Ppar response element } \\ \text { RXR } & \text { Retinoid X receptor } \\ \text { NF- } \text { KB } & \text { Nuclear factor kappa B } \\ \text { TZDs } & \text { Thiazolidenidiones } \\ \text { WAT } & \text { White adipose tissue } \\ \text { BAT } & \text { Brown adipose tissue } \\ \text { FFAs } & \text { Free fatty acids } \\ \text { TGs } & \text { Triglycerides } \\ \text { TNF- } \alpha & \text { Tumor necrosis factor } \alpha \\ \text { PGC1 } \alpha & \text { Peroxisome proliferator-activated receptor gamma coactivator 1-alpha } \\ \text { Ucp-1 } & \text { Uncoupling protein } 1 \\ \text { GDM } & \text { Gestational diabetes mellitus } \\ \text { CR } & \text { Caloric restriction }\end{array}$

\section{References}

1. Virtue, S.; Vidal-Puig, A. Adipose tissue expandability, lipotoxicity and the Metabolic Syndrome-An allostatic perspective. Biochim. Biophys. Acta Mol. Cell Biol. Lipids 2010, 1801, 338-349. [CrossRef] [PubMed]

2. Medina-Gomez, G.; Gray, S.L.; Yetukuri, L.; Shimomura, K.; Virtue, S.; Campbell, M.; Curtis, R.K.; Jimenez-Linan, M.; Blount, M.; Yeo, G.S.H.; et al. PPAR gamma 2 Prevents Lipotoxicity by Controlling Adipose Tissue Expandability and Peripheral Lipid Metabolism. PLoS Genet. 2007, 3, e64. [CrossRef] [PubMed]

3. Venteclef, N.; Jakobsson, T.; Steffensen, K.R.; Treuter, E. Metabolic nuclear receptor signaling and the inflammatory acute phase response. Trends Endocrinol. Metab. 2011, 22, 333-343. [CrossRef] [PubMed]

4. Michalik, L.; Wahli, W. Involvement of PPAR nuclear receptors in tissue injury and wound repair. J. Clin. Investig. 2006, 116, 598-606. [CrossRef] [PubMed]

5. Evans, R.M.; Barish, G.D.; Wang, Y.X. PPARs and the complex journey to obesity. Nat. Med. 2004, 10, 355-361. [CrossRef] [PubMed]

6. Vitale, S.G.; Laganà, A.S.; Nigro, A.; La Rosa, V.L.; Rossetti, P.; Rapisarda, A.M.C.; La Vignera, S.; Condorelli, R.A.; Corrado, F.; Buscema, M.; et al. Peroxisome Proliferator-Activated Receptor Modulation during Metabolic Diseases and Cancers: Master and Minions. PPAR Res. 2016, 2016, 6517313. [CrossRef] [PubMed]

7. Dubrac, S.; Stoitzner, P.; Pirkebner, D.; Elentner, A.; Schoonjans, K.; Auwerx, J.; Saeland, S.; Hengster, P.; Fritsch, P.; Romani, N.; et al. Peroxisome proliferator-activated receptor-alpha activation inhibits Langerhans cell function. J. Immunol. 2007, 178, 4362-4372. [CrossRef] [PubMed]

8. Dalen, K.T.; Schoonjans, K.; Ulven, S.M.; Weedon-Fekjaer, M.S.; Bentzen, T.G.; Kontnikova, H.; Auwerx, J.; Nebb, H.I. Adipose Tissue Expression of the Lipid Droplet-Associating Proteins31 S-S2 and Perilipin Is Controlled by Peroxisome Proliferator-Activated Receptor- $\gamma$. Diabetes 2004, 53, 1243-1252. [CrossRef] [PubMed] 
9. Moore, K.J.; Rosen, E.D.; Fitzgerald, M.L.; Randow, F.; Andersson, L.P.; Altshuler, D.; Milstone, D.S.; Mortensen, R.M.; Spiegelman, B.M.; Freeman, M.W. The role of PPAR-gamma in macrophage differentiation and cholesterol uptake. Nat. Med. 2001, 7, 41-47. [CrossRef] [PubMed]

10. Kersten, S.; Seydoux, J.; Peters, J.M.; Gonzalez, F.J.; Desvergne, B.; Wrahli, W. Peroxisome proliferator-activated receptor alpha mediates the adaptive response to fasting. J. Clin. Investig. 1999, 103, 1489-1498. [CrossRef] [PubMed]

11. Gross, B.; Pawlak, M.; Lefebvre, P.; Staels, B. PPARs in obesity-induced T2DM, dyslipidaemia and NAFLD. Nat. Rev. Endocrinol. 2017, 13, 36-49. [CrossRef] [PubMed]

12. Lalloyer, F.; Wouters, K.; Baron, M.; Caron, S.; Vallez, E.; Vanhoutte, J.; Baugé, E.; Shiri-Sverdlov, R.; Hofker, M.; Staels, B.; et al. Peroxisome proliferator-activated receptor- $\alpha$ gene level differently affects lipid metabolism and inflammation in apolipoprotein E2 knock-in mice. Arterioscler. Thromb. Vasc. Biol. 2011, 31, 1573-1579. [CrossRef] [PubMed]

13. Staels, B.; Maes, M.; Zambon, A. Fibrates and future PPARalpha agonists in the treatment of cardiovascular disease. Nat. Clin. Pract. Cardiovasc. Med. 2008, 5, 542-553. [CrossRef] [PubMed]

14. Holst, D.; Luquet, S.; Nogueira, V.; Kristiansen, K.; Leverve, X.; Grimaldi, P.A. Nutritional regulation and role of peroxisome proliferator-activated receptor $\delta$ in fatty acid catabolism in skeletal muscle. Biochim. Biophys. Acta Mol. Cell Biol. Lipids 2003, 1633, 43-50. [CrossRef]

15. Zoete, V.; Grosdidier, A.; Michielin, O. Peroxisome proliferator-activated receptor structures: Ligand specificity, molecular switch and interactions with regulators. Biochim. Biophys. Acta Mol. Cell Biol. Lipids 2007, 1771, 915-925. [CrossRef] [PubMed]

16. Zingarelli, B.; Piraino, G.; Hake, P.W.; O'Connor, M.; Denenberg, A.; Fan, H.; Cook, J.A. Peroxisome Proliferator-Activated Receptor $\delta$ Regulates Inflammation via NF-кB Signaling in Polymicrobial Sepsis. Am. J. Pathol. 2010, 177, 1834-1847. [CrossRef] [PubMed]

17. Siersbaek, R.; Nielsen, R.; Mandrup, S. PPARgamma in adipocyte differentiation and metabolism-Novel insights from genome-wide studies. FEBS Lett. 2010, 584, 3242-3249. [CrossRef] [PubMed]

18. Ferre, P. The Biology of Peroxisome Proliferator-Activated Receptors: Relationship With Lipid Metabolism and Insulin Sensitivity. Diabetes 2004, 53, S43-S50. [CrossRef] [PubMed]

19. Medina-Gomez, G.; Virtue, S.; Lelliott, C.; Boiani, R.; Campbell, M.; Christodoulides, C.; Perrin, C.; Jimenez-Linan, M.; Blount, M.; Dixon, J.; et al. The link between nutritional status and insulin sensitivity is dependent on the adipocyte-specific peroxisome proliferator-activated receptor-gamma2 isoform. Diabetes 2005, 54, 1706-1716. [CrossRef] [PubMed]

20. Tontonoz, P.; Spiegelman, B.M. Fat and Beyond: The Diverse Biology of PPAR $\gamma$. Annu. Rev. Biochem. 2008, 77, 289-312. [CrossRef] [PubMed]

21. Kubota, N.; Terauchi, Y.; Kubota, T.; Kumagai, H.; Itoh, S.; Satoh, H.; Yano, W.; Ogata, H.; Tokuyama, K.; Takamoto, I.; et al. Pioglitazone ameliorates insulin resistance and diabetes by both adiponectin-dependent and -independent pathways. J. Biol. Chem. 2006, 281, 8748-8755. [CrossRef] [PubMed]

22. Olefsky, J.M. Treatment of insulin resistance with peroxisome proliferator-activated receptor $\gamma$ agonists. J. Clin. Investig. 2000, 106, 467-472. [CrossRef] [PubMed]

23. Odegaard, J.I.; Ricardo-Gonzalez, R.R.; Goforth, M.H.; Morel, C.R.; Subramanian, V.; Mukundan, L.; Red Eagle, A.; Vats, D.; Brombacher, F.; Ferrante, A.W.; et al. Macrophage-specific PPARgamma controls alternative activation and improves insulin resistance. Nature 2007, 447, 1116-1120. [CrossRef] [PubMed]

24. Pellegrinelli, V.; Carobbio, S.; Vidal-Puig, A. Adipose tissue plasticity: How fat depots respond differently to pathophysiological cues. Diabetologia 2016, 59, 1075-1088. [CrossRef] [PubMed]

25. Coelho, M.; Oliveira, T.; Fernandes, R. Biochemistry of adipose tissue: An endocrine organ. Arch. Med. Sci. 2013, 9, 191-200. [CrossRef] [PubMed]

26. Kershaw, E.E.; Flier, J.S. Adipose tissue as an endocrine organ. J. Clin. Endocrinol. Metab. 2004, 89, $2548-2556$. [CrossRef] [PubMed]

27. Brestoff, J.R.; Artis, D. Immune regulation of metabolic homeostasis in health and disease. Cell 2015, 161, 146-160. [CrossRef] [PubMed]

28. Yoneshiro, T.; Aita, S.; Matsushita, M.; Kayahara, T.; Kameya, T.; Kawai, Y.; Iwanaga, T.; Saito, M. Recruited brown adipose tissue as an antiobesity agent in humans. J. Clin. Investig. 2013, 123, 3404-3408. [CrossRef] [PubMed] 
29. Berbée, J.F.P.; Boon, M.R.; Khedoe, P.P.S.J.; Bartelt, A.; Schlein, C.; Worthmann, A.; Kooijman, S.; Hoeke, G.; Mol, I.M.; John, C.; et al. Brown fat activation reduces hypercholesterolaemia and protects from atherosclerosis development. Nat. Commun. 2015, 6, 6356. [CrossRef] [PubMed]

30. Pisani, D.F.; Barquissau, V.; Chambard, J.-C.; Beuzelin, D.; Ghandour, R.A.; Giroud, M.; Mairal, A.; Pagnotta, S.; Cinti, S.; Langin, D.; et al. Mitochondrial fission is associated with UCP1 activity in human brite/beige adipocytes. Mol. Metab. 2018, 7, 35-44. [CrossRef] [PubMed]

31. Bartelt, A.; Bruns, O.T.; Reimer, R.; Hohenberg, H.; Ittrich, H.; Peldschus, K.; Kaul, M.G.; Tromsdorf, U.I.; Weller, H.; Waurisch, C.; et al. Brown adipose tissue activity controls triglyceride clearance. Nat. Med. 2011, 17, 200-205. [CrossRef] [PubMed]

32. Oosterveer, M.H.; Grefhorst, A.; van Dijk, T.H.; Havinga, R.; Staels, B.; Kuipers, F.; Groen, A.K.; Reijngoud, D.-J. Fenofibrate simultaneously induces hepatic fatty acid oxidation, synthesis, and elongation in mice. J. Biol. Chem. 2009, 284, 34036-34044. [CrossRef] [PubMed]

33. Wu, P.; Peters, J.M.; Harris, R.A. Adaptive increase in pyruvate dehydrogenase kinase 4 during starvation is mediated by peroxisome proliferator-activated receptor alpha. Biochem. Biophys. Res. Commun. 2001, 287, 391-396. [CrossRef] [PubMed]

34. Tsuchida, A.; Yamauchi, T.; Takekawa, S.; Hada, Y.; Ito, Y.; Maki, T.; Kadowaki, T. Peroxisome proliferator-activated receptor (PPAR)alpha activation increases adiponectin receptors and reduces obesity-related inflammation in adipose tissue: Comparison of activation of PPARalpha, PPARgamma, and their combination. Diabetes 2005, 54, 3358-3370. [CrossRef] [PubMed]

35. Veiga, F.M.S.; Graus-Nunes, F.; Rachid, T.L.; Barreto, A.B.; Mandarim-de-Lacerda, C.A.; Souza-Mello, V. Anti-obesogenic effects of WY14643 (PPAR-alpha agonist): Hepatic mitochondrial enhancement and suppressed lipogenic pathway in diet-induced obese mice. Biochimie 2017, 140, 106-116. [CrossRef] [PubMed]

36. Kleemann, R.; Gervois, P.P.; Verschuren, L.; Staels, B.; Princen, H.M.G.; Kooistra, T. Fibrates down-regulate IL-1-stimulated C-reactive protein gene expression in hepatocytes by reducing nuclear p50-NFkappa B-C/EBP-beta complex formation. Blood 2003, 101, 545-551. [CrossRef] [PubMed]

37. Wang, W.; Lin, Q.; Lin, R.; Zhang, J.; Ren, F.; Zhang, J.; Ji, M.; Li, Y. PPAR $\alpha$ agonist fenofibrate attenuates TNF- $\alpha$-induced CD40 expression in 3T3-L1 adipocytes via the SIRT1-dependent signaling pathway. Exp. Cell Res. 2013, 319, 1523-1533. [CrossRef] [PubMed]

38. Hondares, E.; Rosell, M.; Díaz-Delfín, J.; Olmos, Y.; Monsalve, M.; Iglesias, R.; Villarroya, F.; Giralt, M. Peroxisome proliferator-activated receptor $\alpha(\operatorname{PPAR} \alpha)$ induces PPAR $\gamma$ coactivator $1 \alpha$ (PGC-1 $\alpha)$ gene expression and contributes to thermogenic activation of brown fat: Involvement of PRDM16. J. Biol. Chem. 2011, 286, 43112-43122. [CrossRef] [PubMed]

39. Rachid, T.L.; Penna-de-Carvalho, A.; Bringhenti, I.; Aguila, M.B.; Mandarim-de-Lacerda, C.A.; Souza-Mello, V. PPAR- $\alpha$ agonist elicits metabolically active brown adipocytes and weight loss in diet-induced obese mice. Cell Biochem. Funct. 2015, 33, 249-256. [CrossRef] [PubMed]

40. Wang, Y.-X.; Lee, C.-H.; Tiep, S.; Yu, R.T.; Ham, J.; Kang, H.; Evans, R.M. Peroxisome-proliferator-activated receptor delta activates fat metabolism to prevent obesity. Cell 2003, 113, 159-170. [CrossRef]

41. Shearer, B.G.; Steger, D.J.; Way, J.M.; Stanley, T.B.; Lobe, D.C.; Grillot, D.A.; Iannone, M.A.; Lazar, M.A.; Willson, T.M.; Billin, A.N. Identification and characterization of a selective peroxisome proliferator-activated receptor beta/delta (NR1C2) antagonist. Mol. Endocrinol. 2008, 22, 523-529. [CrossRef] [PubMed]

42. Kang, K.; Reilly, S.M.; Karabacak, V.; Gangl, M.R.; Fitzgerald, K.; Hatano, B.; Lee, C.-H. Adipocyte-derived Th2 cytokines and myeloid PPARdelta regulate macrophage polarization and insulin sensitivity. Cell Metab. 2008, 7, 485-495. [CrossRef] [PubMed]

43. Hansen, J.B.; Zhang, H.; Rasmussen, T.H.; Petersen, R.K.; Flindt, E.N.; Kristiansen, K. Peroxisome proliferator-activated receptor delta (PPARdelta )-mediated regulation of preadipocyte proliferation and gene expression is dependent on cAMP signaling. J. Biol. Chem. 2001, 276, 3175-3182. [CrossRef] [PubMed]

44. Majithia, A.R.; Tsuda, B.; Agostini, M.; Gnanapradeepan, K.; Rice, R.; Peloso, G.; Patel, K.A.; Zhang, X.; Broekema, M.F.; Patterson, N.; et al. Prospective functional classification of all possible missense variants in PPARG. Nat. Genet. 2016, 48, 1570-1575. [CrossRef] [PubMed]

45. Tang, W.; Zeve, D.; Suh, J.M.; Bosnakovski, D.; Kyba, M.; Hammer, R.E.; Tallquist, M.D.; Graff, J.M. White Fat Progenitor Cells Reside in the Adipose Vasculature. Science 2008, 322, 583-586. [CrossRef] [PubMed]

46. Tontonoz, P.; Hu, E.; Spiegelman, B.M. Stimulation of adipogenesis in fibroblasts by PPAR gamma 2, a lipid-activated transcription factor. Cell 1994, 79, 1147-1156. [CrossRef] 
47. Rosen, E.D.; Sarraf, P.; Troy, A.E.; Bradwin, G.; Moore, K.; Milstone, D.S.; Spiegelman, B.M.; Mortensen, R.M. PPAR gamma is required for the differentiation of adipose tissue in vivo and in vitro. Mol. Cell 1999, 4, 611-617. [CrossRef]

48. Semple, R.K.; Meirhaeghe, A.; Vidal-Puig, A.J.; Schwabe, J.W.R.; Wiggins, D.; Gibbons, G.F.; Gurnell, M.; Chatterjee, V.K.K.; O'Rahilly, S. A dominant negative human peroxisome proliferator-activated receptor (PPAR)\{alpha\} is a constitutive transcriptional corepressor and inhibits signaling through all PPAR isoforms. Endocrinology 2005, 146, 1871-1882. [CrossRef] [PubMed]

49. Gray, S.L.; Nora, E.D.; Grosse, J.; Manieri, M.; Stoeger, T.; Medina-Gomez, G.; Burling, K.; Wattler, S.; Russ, A.; Yeo, G.S.H.; et al. Leptin deficiency unmasks the deleterious effects of impaired peroxisome proliferator-activated receptor gamma function (P465L PPARgamma) in mice. Diabetes 2006, 55, 2669-2677. [CrossRef] [PubMed]

50. Medina-Gomez, G.; Yetukuri, L.; Velagapudi, V.; Campbell, M.; Blount, M.; Jimenez-Linan, M.; Ros, M.; Oresic, M.; Vidal-Puig, A. Adaptation and failure of pancreatic beta cells in murine models with different degrees of metabolic syndrome. Dis. Model. Mech. 2009, 2, 582-592. [CrossRef] [PubMed]

51. Savage, D.B.; Tan, G.D.; Acerini, C.L.; Jebb, S.A.; Agostini, M.; Gurnell, M.; Williams, R.L.; Umpleby, A.M.; Thomas, E.L.; Bell, J.D.; et al. Human metabolic syndrome resulting from dominant-negative mutations in the nuclear receptor peroxisome proliferator-activated receptor-gamma. Diabetes 2003, 52, 910-917. [CrossRef] [PubMed]

52. Yamauchi, T.; Kamon, J.; Waki, H.; Murakami, K.; Motojima, K.; Komeda, K.; Ide, T.; Kubota, N.; Terauchi, Y.; Tobe, K.; et al. The mechanisms by which both heterozygous peroxisome proliferator-activated receptor gamma (PPARgamma) deficiency and PPARgamma agonist improve insulin resistance. J. Biol. Chem. 2001, 276, 41245-41254. [CrossRef] [PubMed]

53. Rangwala, S.M.; Rhoades, B.; Shapiro, J.S.; Rich, A.S.; Kim, J.K.; Shulman, G.I.; Kaestner, K.H.; Lazar, M.A. Genetic modulation of PPARgamma phosphorylation regulates insulin sensitivity. Dev. Cell 2003, 5, 657-663. [CrossRef]

54. Lefebvre, B.; Benomar, Y.; Guédin, A.; Langlois, A.; Hennuyer, N.; Dumont, J.; Bouchaert, E.; Dacquet, C.; Pénicaud, L.; Casteilla, L.; et al. Proteasomal degradation of retinoid $\mathrm{X}$ receptor alpha reprograms transcriptional activity of PPARgamma in obese mice and humans. J. Clin. Investig. 2010, 120, 1454-1468. [CrossRef] [PubMed]

55. Peraldi, P.; Xu, M.; Spiegelman, B.M. Thiazolidinediones block tumor necrosis factor-alpha-induced inhibition of insulin signaling. J. Clin. Investig. 1997, 100, 1863-1869. [CrossRef] [PubMed]

56. Yamauchi, T.; Kamon, J.; Minokoshi, Y.; Ito, Y.; Waki, H.; Uchida, S.; Yamashita, S.; Noda, M.; Kita, S.; Ueki, K.; et al. Adiponectin stimulates glucose utilization and fatty-acid oxidation by activating AMP-activated protein kinase. Nat. Med. 2002, 8, 1288-1295. [CrossRef] [PubMed]

57. Jonker, J.W.; Suh, J.M.; Atkins, A.R.; Ahmadian, M.; Li, P.; Whyte, J.; He, M.; Juguilon, H.; Yin, Y.Q.; Phillips, C.T.; et al. A PPAR $\gamma$-FGF1 axis is required for adaptive adipose remodelling and metabolic homeostasis. Nature 2012, 485, 391-394. [CrossRef] [PubMed]

58. Dutchak, P.A.; Katafuchi, T.; Bookout, A.L.; Choi, J.H.; Yu, R.T.; Mangelsdorf, D.J.; Kliewer, S.A. Fibroblast Growth Factor-21 Regulates PPAR $\gamma$ Activity and the Antidiabetic Actions of Thiazolidinediones. Cell 2012, 148, 556-567. [CrossRef] [PubMed]

59. Ahmadian, M.; Suh, J.M.; Hah, N.; Liddle, C.; Atkins, A.R.; Downes, M.; Evans, R.M. PPAR $\gamma$ signaling and metabolism: The good, the bad and the future. Nat. Med. 2013, 19, 557-566. [CrossRef] [PubMed]

60. Seale, P.; Kajimura, S.; Yang, W.; Chin, S.; Rohas, L.M.; Uldry, M.; Tavernier, G.; Langin, D.; Spiegelman, B.M. Transcriptional Control of Brown Fat Determination by PRDM16. Cell Metab. 2007, 6, 38-54. [CrossRef] [PubMed]

61. Qiang, L.; Wang, L.; Kon, N.; Zhao, W.; Lee, S.; Zhang, Y.; Rosenbaum, M.; Zhao, Y.; Gu, W.; Farmer, S.R.; et al. Brown remodeling of white adipose tissue by SirT1-dependent deacetylation of Ppar $\gamma$. Cell 2012, 150, 620-632. [CrossRef] [PubMed]

62. Metzger, B.E. Long-term Outcomes in Mothers Diagnosed With Gestational Diabetes Mellitus and Their Offspring. Clin. Obstet. Gynecol. 2007, 50, 972-979. [CrossRef] [PubMed]

63. Mericq, V.; Martinez-Aguayo, A.; Uauy, R.; Iñiguez, G.; Van der Steen, M.; Hokken-Koelega, A. Long-term metabolic risk among children born premature or small for gestational age. Nat. Rev. Endocrinol. 2017, 13, 50-62. [CrossRef] [PubMed] 
64. Worda, C.; Leipold, H.; Gruber, C.; Kautzky-Willer, A.; Knöfler, M.; Bancher-Todesca, D. Decreased plasma adiponectin concentrations in women with gestational diabetes mellitus. Am. J. Obstet. Gynecol. 2004, 191, 2120-2124. [CrossRef] [PubMed]

65. Resi, V.; Basu, S.; Haghiac, M.; Presley, L.; Minium, J.; Kaufman, B.; Bernard, S.; Catalano, P.; Hauguel-de Mouzon, S. Molecular inflammation and adipose tissue matrix remodeling precede physiological adaptations to pregnancy. Am. J. Physiol. Endocrinol. Metab. 2012, 303, E832-E840. [CrossRef] [PubMed]

66. Sevillano, J.; de Castro, J.; Bocos, C.; Herrera, E.; Ramos, M.P. Role of insulin receptor substrate-1 serine 307 phosphorylation and adiponectin in adipose tissue insulin resistance in late pregnancy. Endocrinology 2007, 148, 5933-5942. [CrossRef] [PubMed]

67. Catalano, P.M.; Nizielski, S.E.; Shao, J.; Preston, L.; Qiao, L.; Friedman, J.E. Downregulated IRS-1 and PPARgamma in obese women with gestational diabetes: Relationship to FFA during pregnancy. Am. J. Physiol. Endocrinol. Metab. 2002, 282, E522-E533. [CrossRef] [PubMed]

68. Capobianco, E.; Martínez, N.; Fornes, D.; Higa, R.; Di Marco, I.; Basualdo, M.N.; Faingold, M.C.; Jawerbaum, A. PPAR activation as a regulator of lipid metabolism, nitric oxide production and lipid peroxidation in the placenta from type 2 diabetic patients. Mol. Cell. Endocrinol. 2013, 377, 7-15. [CrossRef] [PubMed]

69. Lappas, M. Effect of pre-existing maternal obesity, gestational diabetes and adipokines on the expression of genes involved in lipid metabolism in adipose tissue. Metabolism 2014, 63, 250-262. [CrossRef] [PubMed]

70. Rodriguez-Cuenca, S.; Carobbio, S.; Velagapudi, V.R.; Barbarroja, N.; Moreno-Navarrete, J.M.; Tinahones, F.J.; Fernandez-Real, J.M.; Orešic, M.; Vidal-Puig, A. Peroxisome proliferator-activated receptor $\gamma$-dependent regulation of lipolytic nodes and metabolic flexibility. Mol. Cell. Biol. 2012, 32, 1555-1565. [CrossRef] [PubMed]

71. Vivas, Y.; Díez-Hochleitner, M.; Izquierdo-Lahuerta, A.; Corrales, P.; Horrillo, D.; Velasco, I.; Martínez-García, C.; Campbell, M.; Sevillano, J.; Ricote, M.; et al. Peroxisome Proliferator-Activated Receptor $\gamma 2$ Modulates Late-Pregnancy Homeostatic Metabolic Adaptations. Mol. Med. 2016, 22, 1. [CrossRef] [PubMed]

72. Vivas, Y.; Martínez-García, C.; Izquierdo, A.; Garcia-Garcia, F.; Callejas, S.; Velasco, I.; Campbell, M.; Ros, M.; Dopazo, A.; Dopazo, J.; et al. Early peroxisome proliferator-activated receptor gamma regulated genes involved in expansion of pancreatic beta cell mass. BMC Med. Genom. 2011, 4, 86. [CrossRef] [PubMed]

73. Yessoufou, A.; Hichami, A.; Besnard, P.; Moutairou, K.; Khan, N.A. Peroxisome Proliferator-Activated Receptor $\alpha$ Deficiency Increases the Risk of Maternal Abortion and Neonatal Mortality in Murine Pregnancy with or without Diabetes Mellitus: Modulation of T Cell Differentiation. Endocrinology 2006, 147, 4410-4418. [CrossRef] [PubMed]

74. Kurtz, M.; Capobianco, E.; Martínez, N.; Fernández, J.; Higa, R.; White, V.; Jawerbaum, A. Carbaprostacyclin, a PPARס agonist, ameliorates excess lipid accumulation in diabetic rat placentas. Life Sci. 2010, 86, 781-790. [CrossRef] [PubMed]

75. Barak, Y.; Sadovsky, Y.; Shalom-Barak, T. PPAR Signaling in Placental Development and Function. PPAR Res. 2008, 2008, 1-11. [CrossRef] [PubMed]

76. Gao, Y.; She, R.; Sha, W. Gestational diabetes mellitus is associated with decreased adipose and placenta peroxisome proliferator-activator receptor $\gamma$ expression in a Chinese population. Oncotarget 2017, 8, 113928-113937. [CrossRef] [PubMed]

77. Liu, L.; Zhuang, X.; Jiang, M.; Guan, F.; Fu, Q.; Lin, J. ANGPTL4 mediates the protective role of PPAR $\gamma$ activators in the pathogenesis of preeclampsia. Cell Death Dis. 2017, 8, e3054. [CrossRef] [PubMed]

78. Suwaki, N.; Masuyama, H.; Masumoto, A.; Takamoto, N.; Hiramatsu, Y. Expression and potential role of peroxisome proliferator-activated receptor gamma in the placenta of diabetic pregnancy. Placenta 2007, 28, 315-323. [CrossRef] [PubMed]

79. Carrascosa, J.M.; Andrés, A.; Ros, M.; Bogónez, E.; Arribas, C.; Fernández-Agulló, T.; De Solís, A.J.; Gallardo, N.; Martínez, C. Development of insulin resistance during aging: Involvement of central processes and role of adipokines. Curr. Protein Pept. Sci. 2011, 12, 305-315. [CrossRef] [PubMed]

80. Redman, L.M.; Smith, S.R.; Burton, J.H.; Martin, C.K.; Il'yasova, D.; Ravussin, E. Metabolic Slowing and Reduced Oxidative Damage with Sustained Caloric Restriction Support the Rate of Living and Oxidative Damage Theories of Aging. Cell Metab. 2018, 27, 805. [CrossRef] [PubMed] 
81. Carobbio, S.; Pellegrinelli, V.; Vidal-Puig, A. Adipose Tissue Function and Expandability as Determinants of Lipotoxicity and the Metabolic Syndrome. Adv. Exp. Med. Biol. 2017, 960, 161-196. [PubMed]

82. Sun, K.; Tordjman, J.; Clément, K.; Scherer, P.E. Fibrosis and adipose tissue dysfunction. Cell Metab. 2013, 18, 470-477. [CrossRef] [PubMed]

83. Cha, D.R.; Zhang, X.; Zhang, Y.; Wu, J.; Su, D.; Han, J.Y.; Fang, X.; Yu, B.; Breyer, M.D.; Guan, Y. Peroxisome proliferator activated receptor alpha/gamma dual agonist tesaglitazar attenuates diabetic nephropathy in $\mathrm{db} / \mathrm{db}$ mice. Diabetes 2007, 56, 2036-2045. [CrossRef] [PubMed]

84. Khan, T.; Muise, E.S.; Iyengar, P.; Wang, Z.V.; Chandalia, M.; Abate, N.; Zhang, B.B.; Bonaldo, P.; Chua, S.; Scherer, P.E. Metabolic Dysregulation and Adipose Tissue Fibrosis: Role of Collagen VI. Mol. Cell. Biol. 2009, 29, 1575-1591. [CrossRef] [PubMed]

85. Huh, J.Y.; Park, Y.J.; Ham, M.; Kim, J.B. Crosstalk between adipocytes and immune cells in adipose tissue inflammation and metabolic dysregulation in obesity. Mol. Cells 2014, 37, 365-371. [CrossRef] [PubMed]

86. Xu, L.; Ma, X.; Verma, N.K.; Wang, D.; Gavrilova, O.; Proia, R.L.; Finkel, T.; Mueller, E. Ablation of PPAR $\gamma$ in subcutaneous fat exacerbates age-associated obesity and metabolic decline. Aging Cell 2018, 17, e12721. [CrossRef]

87. Miard, S.; Dombrowski, L.; Carter, S.; Boivin, L.; Picard, F. Aging alters PPARgamma in rodent and human adipose tissue by modulating the balance in steroid receptor coactivator-1. Aging Cell 2009, 8, 449-459. [CrossRef] [PubMed]

88. Park, J.; Choe, S.S.; Choi, A.H.; Kim, K.H.; Yoon, M.J.; Suganami, T.; Ogawa, Y.; Kim, J.B. Increase in Glucose-6-Phosphate Dehydrogenase in Adipocytes Stimulates Oxidative Stress and Inflammatory Signals. Diabetes 2006, 55, 2939-2949. [CrossRef] [PubMed]

89. De Pauw, A.; Tejerina, S.; Raes, M.; Keijer, J.; Arnould, T. Mitochondrial (dys)function in adipocyte (de)differentiation and systemic metabolic alterations. Am. J. Pathol. 2009, 175, 927-939. [CrossRef] [PubMed]

90. Tormos, K.V.; Anso, E.; Hamanaka, R.B.; Eisenbart, J.; Joseph, J.; Kalyanaraman, B.; Chandel, N.S. Mitochondrial complex III ROS regulate adipocyte differentiation. Cell Metab. 2011, 14, 537-544. [CrossRef] [PubMed]

91. Mennes, E.; Dungan, C.M.; Frendo-Cumbo, S.; Williamson, D.L.; Wright, D.C. Aging-associated reductions in lipolytic and mitochondrial proteins in mouse adipose tissue are not rescued by metformin treatment. J. Gerontol. A Biol. Sci. Med. Sci. 2014, 69, 1060-1068. [CrossRef] [PubMed]

92. Hallgren, P.; Sjöström, L.; Hedlund, H.; Lundell, L.; Olbe, L. Influence of age, fat cell weight, and obesity on $\mathrm{O}_{2}$ consumption of human adipose tissue. Am. J. Physiol. 1989, 256, E467-E474. [CrossRef] [PubMed]

93. Graier, W.F.; Malli, R.; Kostner, G.M. Mitochondrial protein phosphorylation: Instigator or target of lipotoxicity? Trends Endocrinol. Metab. 2009, 20, 186-193. [CrossRef] [PubMed]

94. Schosserer, M.; Grillari, J.; Wolfrum, C.; Scheideler, M. Age-Induced Changes in White, Brite, and Brown Adipose Depots: A Mini-Review. Gerontology 2018, 64, 229-236. [CrossRef] [PubMed]

95. Shin, W.; Okamatsu-Ogura, Y.; Machida, K.; Tsubota, A.; Nio-Kobayashi, J.; Kimura, K. Impaired adrenergic agonist-dependent beige adipocyte induction in aged mice. Obesity 2017, 25, 417-423. [CrossRef] [PubMed]

96. Sung, B.; Park, S.; Yu, B.P.; Chung, H.Y. Modulation of PPAR in aging, inflammation, and calorie restriction. J. Gerontol. A Biol. Sci. Med. Sci. 2004, 59, 997-1006. [CrossRef] [PubMed]

97. Mukherjee, R.; Hoener, P.A.; Jow, L.; Bilakovics, J.; Klausing, K.; Mais, D.E.; Faulkner, A.; Croston, G.E.; Paterniti, J.R. A selective peroxisome proliferator-activated receptor-gamma (PPARgamma) modulator blocks adipocyte differentiation but stimulates glucose uptake in 3T3-L1 adipocytes. Mol. Endocrinol. 2000, 14, 1425-1433. [CrossRef] [PubMed]

98. Schwartz, A.V. Diabetes, TZDs, and Bone: A Review of the Clinical Evidence. PPAR Res. 2006, $2006,24502$. [CrossRef] [PubMed]

99. Kung, J.; Henry, R.R. Thiazolidinedione safety. Expert Opin. Drug Saf. 2012, 11, 565-579. [CrossRef] [PubMed]

100. Fan, W.; Evans, R. PPARs and ERRs: Molecular mediators of mitochondrial metabolism. Curr. Opin. Cell Biol. 2015, 33, 49-54. [CrossRef] [PubMed]

101. Hevener, A.L.; He, W.; Barak, Y.; Le, J.; Bandyopadhyay, G.; Olson, P.; Wilkes, J.; Evans, R.M.; Olefsky, J. Muscle-specific Pparg deletion causes insulin resistance. Nat. Med. 2003, 9, 1491-1497. [CrossRef] [PubMed] 
102. Fabbiano, S.; Suá Rez-Zamorano, N.; Rigo, D.E.; Veyrat-Durebex, C.; Stevanovic Dokic, A.; Colin, D.J.; Trajkovski, M. Caloric Restriction Leads to Browning of White Adipose Tissue through Type 2 Immune Signaling. Cell Metab. 2016, 24, 1-13. [CrossRef] [PubMed]

103. Mitchell, S.J.; Madrigal-Matute, J.; Scheibye-Knudsen, M.; Fang, E.; Aon, M.; González-Reyes, J.A.; Cortassa, S.; Kaushik, S.; Gonzalez-Freire, M.; Patel, B.; et al. Effects of Sex, Strain, and Energy Intake on Hallmarks of Aging in Mice. Cell Metab. 2016, 23, 1093-1112. [CrossRef] [PubMed]

104. Escrivá, F.; Gavete, M.L.; Fermín, Y.; Pérez, C.; Gallardo, N.; Alvarez, C.; Andrés, A.; Ros, M.; Carrascosa, J.M. Effect of age and moderate food restriction on insulin sensitivity in Wistar rats: Role of adiposity. J. Endocrinol. 2007, 194, 131-141. [CrossRef] [PubMed]

105. Gabriely, I.; Ma, X.H.; Yang, X.M.; Atzmon, G.; Rajala, M.W.; Berg, A.H.; Scherer, P.; Rossetti, L.; Barzilai, N. Removal of visceral fat prevents insulin resistance and glucose intolerance of aging: An adipokine-mediated process? Diabetes 2002, 51, 2951-2958. [CrossRef] [PubMed]

106. Masternak, M.M.; Bartke, A. PPARs in Calorie Restricted and Genetically Long-Lived Mice. PPAR Res. 2007, 2007, 28436. [CrossRef] [PubMed]

107. Wilson-Fritch, L.; Nicoloro, S.; Chouinard, M.; Lazar, M.A.; Chui, P.C.; Leszyk, J.; Straubhaar, J.; Czech, M.P.; Corvera, S. Mitochondrial remodeling in adipose tissue associated with obesity and treatment with rosiglitazone. J. Clin. Investig. 2004, 114, 1281-1289. [CrossRef] [PubMed]

(c) 2018 by the authors. Licensee MDPI, Basel, Switzerland. This article is an open access article distributed under the terms and conditions of the Creative Commons Attribution (CC BY) license (http://creativecommons.org/licenses/by/4.0/). 